\title{
Learning from ribozymes
}

\author{
DAN HERSCHLAG \\ Department of Biochemistry, Stanford University School of Medicine, Stanford, California 94305-530, USA
}

I had arranged to meet Tom Cech after the Pfizer Lecture he was giving at Harvard. This was 1986, RNA catalysis was pretty new, and I was a graduate student nearby at Brandeis interested in discussing with Tom the possibility of joining his group for a postdoc. His lecture was masterful-the audience in rapt attention. We all knew, and were taught, that enzymes were proteins-so how could RNA do the job of a protein?

Perhaps I was a bit brash in my youth. But coming from Brandeis, with Bill Jencks, Bob Abeles, Chris Miller, and others who lived and breathed mechanism, it was apparent that there was no real understanding of how the ribozyme was acting. So my opening to Tom was, "That was incredible how everyone was so fascinated by your talk. In my postdoc I want to learn enough about the ribozyme so that, when you come back to Harvard in a few years, how it works will be so obvious that the audience will be bored."

While I don't recommend this as an opening for a job interview, I do think this story illustrates how the RNA field has been fueled by cycles of discovery-uncovering of mysteries-followed by "detailed" work to reveal mechanism and provide understanding. This is likely true-or should be true- - for all areas of science, though the discoveries about and around RNA have been particularly startling and impactful, and many mysteries remain to be unraveled. As part of this Anniversary celebration of the RNA journal and the field that it represents, I recount how some of RNA's mysteries have been unmasked. Given RNA's many important and complex biological roles, there is no dearth of new mysteries awaiting this generation of RNA scientists. This is truly an exciting time.

After the initial discoveries of RNA catalysts and after the dust settled around the debates of whether these observations were true and whether RNA was allowed to be called an "enzyme,"1 there was a growing unease and even disappointment that many, many more ribozymes were not discovered. There were of course interesting and important ones, but maybe their relative sparseness helped the field in other

\footnotetext{
${ }^{1}$ Arthur Kornberg never relented, but he did allow me to be hired into his Biochemistry Department, so it couldn't have been an irreconcilable issue for him.

Corresponding author: herschla@stanford.edu

Article and publication date are at http://www.rnajournal.org/cgi/doi/ 10.1261/rna.050914.115. Freely available online through the RNA Open Access option.
}

ways, turning attention from discovery to deeper mechanistic understanding.

There is an important lesson here: as "omics" have become more and more powerful and more and more commonplace, "discovery" becomes easier and easier. But this discovery, while necessary and important, leaves us with lists of factors and interactions, whereas the properties and behavior of molecules, complexes, and systems follow rules determined by chemistry and physics, and have come to exist through probabilistic events governed by natural selection. Thus, a deep understanding of biology, ultimately, requires descriptions in the language of chemistry, physics, and evolution. The understanding that has, to date, been garnered by mechanistic investigation of ribozyme folding, structure, and function has profoundly deepened and broadened our understanding of biology and of RNA as a functional macromolecule. Below I briefly recount some of what's been learned through indepth studies of ribozymes.

As the adrenaline rush of discovery began to wear off, questions of how RNA performs catalysis ascended (see below). And while there were limited numbers of new ribozymes discovered, it was recognized that studies of catalysis could be more broadly useful, providing powerful readouts for structure and structural and dynamic properties. Correspondingly, seminal research on RNA folding was carried out using ribozymes by Ulhenbeck, Williamson, Pan, Sosnick, and others. That and earlier work on tRNA made it abundantly clear that RNA has a strong propensity to misfold. This recognition led to our work establishing the ability of proteins to act as RNA chaperones, which in turn led to the RNA Chaperone Hypothesis. Indeed, it was our detailed kinetic and thermodynamic framework for the hammerhead ribozyme reaction that allowed us to initially interpret and understand chaperone behavior. Analogously, the detailed kinetic and thermodynamic framework for folding of the Tetrahymena group I ribozyme allowed Russell to uncover the basic modes of action of RNA-dependent ATPases. These DEAD-box and related proteins are involved in every aspect of biology where RNA appears and share

(C) 2015 Herschlag This article, published in RNA, is available under a Creative Commons License (Attribution-NonCommercial 4.0 International), as described at http://creativecommons.org/licenses/by-nc/4.0/. 
structural features with DNA helicases, but are mechanistically distinct.

Above I used the term "detailed" purposely, because it is common to dismiss such research efforts as "just the details." But broad biological insights can arise from details-by placing the right details placed into a broader perspective. With respect to RNA chaperones, the idea arose that Nature needs to address a fundamental limitation of RNA - its strong stabilizing forces compel RNA to need "help" to be unfolded in the cell in order to achieve its functional (folded or unfolded) conformations on biological timescales-thus the proposal, later established, that Biology employs proteins that act as RNA chaperones. This idea also provided a model for a "missing link" in the RNA World hypothesis-in terms of the transition from an RNA world to our modern world with function dominated by proteins. The simple idea is that non-specific proteins or peptides acting as RNA chaperones could have provided the first functions and thus the first selective pressure to develop and optimize a protein synthesis machinery, thereby allowing an entré for proteins into the RNA world without the need for invoking extraordinarily improbable occurrence of a random founder protein that exhibited specific recognition or catalysis.

Returning to the original question, how do RNAs function as enzymes? One early idea was that $\mathrm{Mg}^{2+}$ ions were fully responsible for RNA catalysis, and explanations included allusion to Lewis Carroll's Cheshire Cat, where the role of $\mathrm{Mg}^{2+}$ might be akin to the cat's smile that remained after the cat's body-or the ribozyme's RNA-disappeared. However, to paraphrase Churchill, this might be wrapping a mystery (catalysis) in an enigma (Lewis Carroll's Cheshire Cat) rather than providing a satisfying molecular explanation or model. Other mysteries presented were the "special" role of $2^{\prime}$-hydroxyl groups in nucleic acid function-after all, there were no DNA catalysts, ${ }^{2}$ and the "special" role of $\mathrm{Mg}^{2+}$, as opposed to other cations, in RNA folding.

${ }^{2}$ Indeed, so strong was the belief that RNA and DNA were distinct entities that I was able to place, and win, and wager that a ribozyme would be able to cleave DNA and not just RNA. So surprising was this discovery - at the time - that it was published in the general interest magazine Nature.
These mysteries receded though, as detailed functional and structural studies allowed chemical and physical understanding to replace observations, notions, and analogies. ${ }^{3}$ For example, DNA enzymes were found by selection, and ribozymes were found that could provide catalysis in the absence of $\mathrm{Mg}^{2+}$ or other divalent cations. In-depth functional and structural studies revealed that RNA enzymes, like protein enzymes, were shown to use multiple catalytic strategies, binding interactions and energy to position substrates and catalytic groups with respect to one another and so-called catalytic groups (including $\mathrm{Mg}^{2+}$ ) to stabilize charge accumulation and to facilitate protonation and deprotonation events. Some of the approaches used in these studies were extended from simple ribozyme systems to comparative analyses of group II and spliceosomal splicing by Piccirilli and Staley to provide compelling evidence for a conserved splicing mechanism. The "special" roles of $\mathrm{Mg}^{2+}$ in RNA folding turned out to be specific metal ion binding sites that are present in the folded structure but not the unfolded structure (so that folding is driven by thermodynamically coupled $\mathrm{Mg}^{2+}$ binding) and the ability of $\mathrm{Mg}^{2+}$ (and other divalent cations) to lessen the increased electrostatic repulsion upon folding to a more compact state much more effectively than monovalent cations-a property predicted by rudimentary polyelectrolyte theories and spelled out by Draper.

There is an inherent value in fundamental understanding grounded in physics and chemistry, as I have tried to illustrate above. This type of understanding needs to permeate still deeper into biology and medicine. Given the remarkable roles of RNA, there will be plenty of opportunities for RNA scientists-in non-coding RNAs, RNA/protein interaction networks, pre-mRNA splicing and alternative splicing mechanisms, and the regulation of translation and other RNAmediated processes - to provide deep mechanistic understanding and insights in the coming years.

${ }^{3}$ While analogies can help our understanding, they can also be misleading as there are often distinct physical origins for the processes being compared. 

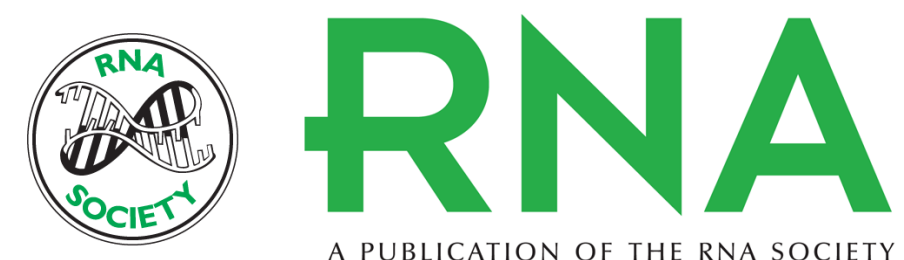

A PUBLICATION OF THE RNA SOCIETY

\section{Learning from ribozymes}

Dan Herschlag

RNA 2015 21: 527-528

Open Access Freely available online through the RNA Open Access option.

Creative This article, published in $R N A$, is available under a Creative Commons License Commons (Attribution-NonCommercial 4.0 International), as described at License http://creativecommons.org/licenses/by-nc/4.0/.

Email Alerting Receive free email alerts when new articles cite this article - sign up in the box at the Service top right corner of the article or click here. 